International Journal of Literature Studies (IJLS)

ISSN: $2754-2610$

DOI: $10.32996 /$ ijts

Journal Homepage: www.al-kindipublisher.com/index.php/ijlss

\title{
The Postmodern Multi-Layered Narrative of Existential Feminist Subjectivity: The Case of Margaret Atwood's Alias Grace
}

\author{
Hazmah Ali Al-Harshan \\ Assistant Professor at the Department of Languages and Translation, Faculty of Education and Arts, University of Tabuk, Saudi \\ Arabia
}

$\square$ Corresponding Author: Hazmah Ali Al-Harshan, E-mail: halhrshan@ut.edu.sa

\section{ARTICLE INFORMATION \\ Received: 11 September 2021 \\ Accepted: 01 October 2021 \\ Published: 19 October 2021 \\ DOI: 10.32996/ijts.2021.1.1.6}

\section{KEYWORDS}

Narrativization of history, doublevoiced, Bakhtin, multiplicity narrative, recuperation of the silenced voice.

\section{ABSTRACT}

Postmodern fiction demonstrates a suspicion about the narrative status of history. Arguably, its project is to reveal the illusion of truth in history because of history's reliance on texts. There is no doubt that historical events occur, but their transmutation into "fact" and their transmission to posterity are limited by their narrativization and textualization. In the Afterword to her novel, Alias Grace (1996) - a fictionalized narrative centering on a real-life person embroiled in a double murder in $1843-$ Margaret Atwood reveals her interest in this problem with "history". She tells the reader, "I have of course fictionalized historical events ... as did many commentators on this case who claimed to be writing history". The purpose of this paper is thus to consider Margaret Atwood's novel, Alias Grace as a postmodern fiction that seeks to reveal the illusion of truth in history through her use of innovatory narrative techniques. Mikhail Bakhtin's notion of the "double-voiced" is used to examine the permitted, surface-level utterances - and the necessarily conflicting actual narratives - of the two narrators in Atwood's novel. However, the term is also applied in the broader feminist/theoretical context of the silencing of the female subject more generally. Atwood establishes a fragmented, multiplicity narrative. This arises from the reported and somewhat self-aware observations of the eponymous Grace and a doctor named Simon Jordan. Seemingly, the author's own authority does not exist. Atwood thus exploits the slippery nature of language that does not have some kind of "truth" imposed upon it. The historical "truth" about Grace Marks is never revealed, not because Atwood is "leaving it to the reader's imagination" but because Atwood plays with the problem of personality as a social construction. Almost invisible as "author", Atwood nevertheless reveals just how language can be manipulated and made to conform to a certain version of 'truth' and 'reality'. However, in Alias Grace, Atwood also recuperates the voice of a supposedly murderous woman by revising the myth of woman's silence and subjugation. Because her speaking voices are required to practice "double-voicing" to be heard, through presenting the reader with both voices, Atwood recuperates the moments of existential liberation to be heard from emergent voices.

Postmodern fiction demonstrates a suspicion about the narrative status of history. History is no longer a world of truth, but a sequence of fabricated devices and invented compositions. This skepticism about the truth value of history indicates an innate resistance to the language and conventions of realism. Arguably, postmodern fiction seeks to reveal the illusion of truth in history because of history's reliance on texts. Documents and artifacts used to reconstruct history cannot be neutral and thus, every representation of the past has discoverable ideological implications. Hayden White goes so far as to argue that "narrativizing discourse serves the purpose of moralizing judgments" (24). He observes that the supposed "objectivity" of narrativity in its representations of reality, in both history and fiction, does not actually reproduce the event it describes: it simply shows a possible

Copyright: (c) 2021 the Author(s). This article is an open access article distributed under the terms and conditions of the Creative Commons Attribution (CC-BY) 4.0 license (https://creativecommons.org/licenses/by/4.0/). Published by Al-Kindi Centre for Research and Development, London, United Kingdom. 
interpretation of it. However, Linda Hutcheon at least partially banishes the specter of relativism, even total nihilism, inherent in assuming the impossibility of "true" representation when she says that "to speak provisionally and indeterminacy is not to deny historical knowledge" (88). There is no doubt about the occurrence of a historical event, but its transmutation into "fact" and its transmission to us is limited by its narrativization and textualization. Historical knowledge is thus posited as an object of (historically- and culturally contingent) narrative representation through the medium of language. Indeed, it is suggested here that narrative transforms knowledge of events into a mere historical discourse.

The purpose of this paper is to consider Margaret Atwood's narrative technique in Alias Grace (1996) through the lens of Mikhail Bakhtin's notion of "double-voiced" discourse. Bakhtin's term may be used to describe the constraints that an interlocutor (usually one who feels in a position of lesser power) places upon his or her speech in order to render his or her utterances acceptable to the agenda of the speech partner. However, here, the term has a dual application. In the purely literary context, the term will be applied to the permitted speech - and the actual narratives - of the narrators in Atwood's novel. It will also be used in the broader feminist/theoretical context relating to the silencing / decentring / manipulation of the female subject in general. Atwood establishes a fragmented, multiplicity narrative in the novel. This arises naturally from the reported and somewhat selfaware observations of two major characters, Grace Marks and Simon Jordan. Seemingly, the author's authority does not exist; Atwood exploits the slippery nature of language that does not have some kind of "truth" imposed upon it. The historical "truth" about Grace Marks is never revealed, not because Atwood is "leaving it to the reader's imagination to do the work" but because Atwood plays with the problem of personality as a social construction. Grace Marks is undoubtedly a historically determined character. Bakhtin's assertion, in "Discourse in the Novel" (1941), that "the direct intention of the character who is speaking" supplies access to "the refracted intention of the author" (324) suggestively illuminates Atwood's narrative design. She interrupts the categorical organization of character identity by depicting "selves" that are always in dialogue with (what Bakhtin would term) their current desires and the alien contexts into which they are cast. Through the direct expression of her speakers, as they struggle for existential identity between "the express planes of various belief systems" (290), Atwood reveals her own position as a narrator. She challenges the social and ideological autonomy of voices through the construction of narrative. Her control over the narrative structure, or what Bakhtin would term "the diazotization" of her narrators, reveals her insight into the insufficiency of predictable cultural and gendered definitions in the identity struggles of her protagonists.

Atwood's characters exist in a constant struggle to define their experience as it exceeds their essential beliefs regarding the boundaries of their existence. Thus, in their very struggle, they may be seen to engage with Jean-Paul Sartre's assertion, stated in Being and Nothingness, that human existence is intrinsically characterized by a capacity to negate what is and contrast it with what might be - and by individual freedom and responsibility (44). In "Existentialism Is a Humanism," Sartre also asserts that "existentialism, in our sense of the word, is a doctrine that ... affirms that every truth and every action [and implies] both an environment and a human subjectivity" (288). He strongly emphasizes freedom of choice and, in addition, responsibility. Thus, by extension, he argues that in choosing our own essence, we are choosing, in a way, for all humankind: "every man, without any support or help whatever, is condemned at every instant to invent man" (291). In Atwood's novel, the eponymous Grace is portrayed as an outcast woman who is placed in a multiplicity of roles and positions constructed by others. Her engagement with this multiplicity of roles represents an existential resistance to masculine organizational and structuring discourses. Atwood is very concerned with language and how it structures perceptions and 'truths.' She may be seen to deconstruct language in an attempt to reveal just how it can be manipulated and be made to conform to a certain version of 'truth' and 'reality'. In Alias Grace, Atwood explores how language has been used to construct an image of woman as the 'other' or the 'object' who is inherently subordinate to the patriarchal subject.

Throughout Alias Grace, the manipulations create a kind of narrative twisting. Grace's voice is clearest when cultural and sexual positioning in speech is seen to contribute to her existential identity. The tension between the reader's need for a consistent discourse and the actual ambiguity of narrative seems to split the subjectivity of Atwood's female character. Grace's words, for instance, depend upon who remembers them, and thus they repeatedly shift the balance between expected and problematizing self-disclosures. The sense here is that active voices must be allowed to negotiate between points of view. Or, as Bakhtin would put it, animate voices repeatedly "take Words from other people's mouths"; their language is, in effect, "over-populated with the intentions of others" (291). In this sense, the personal narratives Atwood constructs explore the appeals and restrictions of possible identities. Grace's unfolding history, for example, relies upon and is spoken through, interconnecting discourses. Because Grace is cast in this role as an undefined type of woman (villain or victim), she becomes a mystery that everyone can attempt to solve. Grace, thinking "of all the things that have been written about her", lists the various "selves" that have been thrust upon her:

I am an inhuman female demon ...I am an innocent victim of a blackguard forced against my will and in danger of my own life ... I was too ignorant to know how to act and that to hang me would be judicial murder ... I am a good girl with a pliable nature and no harm is told of me ... I am cunning and devious ... I am soft in the head and little better than an idiot. (23) 
It is small wonder that she concludes her ruminations with the thought, "And I wonder, how can I be all of these different things at once?" (23).

Grace's existential inner being is created by the influence of the languages around her. In a sense, she speaks of the very process which, as Kenneth Ramchand puts it, is "the process of assimilation into the dominant culture in which one's social status is based upon one's proximity to the norm" (36). Grace speaks of the material from which she must construct an existential identity. Bewilderingly for Grace, no single discourse is privileged as the predominant representation of her inner subjectivity, and through similar discursive blending, the same is true for her fellow narrators. Thus, Atwood's narrative equalizes her experience with that of others who also struggle for self-expression.

Atwood's female speaking voice demonstrates that there are no isolated vocabularies through which a woman can express herself, that they are all the product of a complex blending of discourses. As Isabella Dow points out, "The resounding [cause of the] struggle of the women of Alias Grace ... is that no one seems to hear, listen to, or believe them when they speak. This contemptible dynamic is one that sounds bitterly familiar, and reminds audiences of the hazards of falling into that trap" (3). Atwood could not have made Grace the only narrator in the text. Her identity (and her struggle to articulate it) relies upon her words being heard in contrast and connection to other speakers. Herein, Atwood's female speaker shows us something beyond what Bakhtin's theory of double-voicing might suggest. Atwood and her speakers emerge into selfhood (that is, existential being) through their negotiations among "the express planes of various belief systems." In the process, they also demonstrate that language itself does not exist in self-contained, static structures. These fictional speakers refuse to abide by the principle that there are identifiable boundaries between belief systems. Atwood's emphasis on the performance of voice means that she creates in her fiction a life-like depiction of the active interplay of these belief systems.

The verbal frameworks of belief systems seem most clearly connected to "the paradox," that Joanne Creighton points out, in which feminists so often find themselves. Creighton argues that in regarding "patriarchal discourse as fiction" feminists "nevertheless proceed as if our position, based on a belief in the oppression of women, were somewhat closer to the truth" (67). But because the narrative authority does not reside in one voice in Alias Grace, Atwood dethrones the notion of "truth" as something hidden in the stories we have never heard before. We cannot turn Grace into a reliable narrator in this text.

Yet if the novel fails to reveal a single, cohesive truth about Grace's involvement with the Kinnear/Montgomery murders, then what does it reveal? Atwood writes in her Afterword, "I have of course fictionalized historical events (as did many commentators on this case who claimed to be writing history)" (464). Atwood was obviously drawn to, if not finishing Grace Marks' story, then exposing the limitations of historical authority. As Peter Brooks demonstrates, "any narrative ... is hermeneutic in intention, claiming to retract even in order to make it available to consciousness" (34). Meanwhile, the recorded details about Grace Marks' life go one stage further than offering a single dubious history - the accounts contradict each other. It might be asked, therefore whether any of these narratives can be regarded as reliable - as embodying "the truth"? The tangled web of interlocking, though conflicting, narratives express the irrationality of the world and exposes the limitation and absurdity of human reason.

According to Bakhtin's notion of double-voicing, Grace does not proffer a truth to be authorized from among the things people think of her. She seems to "try on" several truths to see if they fit her; she also speaks with a dual agenda. At one point in the novel, she says that:

The right thing to do was, not to tell the story as I truly remembered it, which nobody could be expected to make any sense of, but to tell a story that would hang together, and that had some chance of being believed. I was to leave out the parts that I couldn't remember, and especially to leave out the fact that I could not remember them. And I should say what must have happened, according to plausibility, rather than what I myself could actually recall. So that is what I attempted to do. (357)

This might be considered as a paradigm for writing any kind of history.

Grace likes the sound of the word murderess, "a strong word to have attached to you... It rustles, like a taffeta skirt across the floor." She says, "I would rather be a murderess than a murderer if those are the only choices" (22-23). Her arrest and the suspicion of her intimacy with both James McDermott and Mr. Kinnear make her already-ruined reputation far worse. From the low but innocuous rank of a housemaid, she becomes "the villain/murderer". She is the fascinating (as well as feared demon) object for the Governor's wife and daughters; also, to the prison guards, her doctors at the asylum, her fellow inmates, and to the spectators who come to stare at her as the star attraction of both Kingston Penitentiary and the Lunatic Asylum.

Since Grace embodies the labyrinth of uncertainty about "true" history, everyone in her world continually tries to extract the truth from her about her part in the Kinnear and Montgomery murders. Her jailer, other inmates, Kenneth Mackenzie, psychiatrists, De. Verringer, the liberal ladies' circles, the Governor's wife and daughters - everyone wants to know the dark secret: did she, or didn't she kill the two victims? All parties try to formulate a truth based on justifying their own assumptions about Grace 
herself. What they all have in common is the longing to be empowered to elicit 'truth.' We find ourselves as readers optimistically anticipating that the therapeutic relationship between Grace and Simon will allow the 'truth' to be revealed. We expect that the Narrative labyrinth of uncertainty will resolve itself into a definitive "answer" to the question about what actually happened because Simon earns Grace's trust.

Grace narrates that "a chill ran over her whole body," because "he has been very kind to her, and is also a considerable diversion in her life of monotony and toil" (381). But, startlingly, in spite of this relationship, the narrative discourse reverses the expectations of the reader. It can offer only an illusion and impossible answers. Grace rejects the community's authority, offering in place of answers only silence and forgetfulness. In response, those such as the former asylum keeper, Dr. Bannerling, who believes Grace to be guilty of the murders throughout, interpret her natural desire for self-preservation as evil. Meanwhile, Grace retains tight control over her revelations and tells Simon only what she wants to tell him. She is extremely aware of her dual roles as servant and villain woman. Throughout the novel, her internal and unspoken answers to Simon's questions continue to show her existential struggle to reveal the truth. She suppresses intelligent and interactive conversation with Simon instead giving him her "good stupid look which [she has] practiced" (58).

The self-control by which "butter wouldn't melt in her mouth," according to a barkeep in Richmond Hill (383), allows her to skillfully alternate between resisting and embracing the role of storyteller, the beauty and complexity of which lies in the ambiguity surrounding consciousness, intention, and truth. It's even possible that what Dr. Bannerling writes of Grace in the lunatic asylum is also true of her talks with Simon. The senior alienist was convinced that she:

[W]as attempting to pull the wool over [Bannerling's] eyes in a studied and flagrant manner. To speak plainly, her madness was a fraud and an imposture, adopted by her in order that she might indulge herself and be indulged, the strict regimen of the Penitentiary, where she had been placed as a just punishment for her atrocious crimes, not having been to her liking. (71)

So, when Grace mourns Simon's eventual flight from Kingston, she may lose the demand of mere freedom to speak. She, at least in part, mourns the loss of the right to speak - even if she deliberately chooses to withhold information from him. Late in the novel, Grace tells Simon in a letter, which we're not sure he receives, that "I was enjoying our talks; but also, they said you were to write a letter to the Government on my behalf, to set me free, and I was afraid that now you would never do so" (422). It is unclear whether Grace grieves for the loss of the[?] possibility of release from prison, or for the fellow-feeling or even love for Simon, or possibly even for her manipulated narrative with readers.

In Grace's labyrinthine narrative, there is slippage between what is true memory and what may be storytelling contrived to please Simon and herself. Simon admits in a letter [to whom?] that "Although [Grace] converses in what seems a frank enough manner, she manages to tell as little as possible, or as little as possible of what I want to learn" (133). The real obstacle to Simon in the task of constructing and authorizing the 'truth' is Grace's amnesia relating to the exact time of the murders. According to Atwood critic Karen Stein, "Grace ... tells [Simon in] poetic and detailed language everything but the one thing he wishes to know: what her involvement was in the murders of Nancy Montgomery and Thomas Kinnear" (109).

Freud writes that the task of psychoanalysis "is to make conscious everything that is pathologically unconscious" thus "its task is to fill up all the gaps in the patient's memory, to remove his amnesias" (350). However, in this post-Freudian novel about pre-Freudian psychiatry, this never happens. At one point of the novel, Simon explains to Reverend Verringer that "[o]ur subject appears to remember her life before arriving at Mr. Kinnear's, with a vividness, and a mass of circumstantial detail, that indicates the problem is not with her memory in general" (188).

The memories Simon does try to make sense of are Grace's fainting spells and vivid dreams. Her black-out after Mary Whitney's death he construes as "the only memory she seems to have forgotten; otherwise, every button and candle-end seems accounted for" (185). Her Armageddon-like dream the week before the murders and her recurring dream about Nancy and the red peonies offer an alleged look at Grace's unconscious, but they are certainly no more reliable than her memories. The mere telling of them constitutes the reconstruction of memory, and it's hardly reassuring when Grace notes: "Dr. Jordan is writing eagerly as if his hand can scarcely keep up, and I have never seen him so animated before. It does my heart good to feel that I Can bring a little pleasure into a fellow-being's life, and I think to myself, I wonder what he will make of all that (281). Is her heart 'done good' to have recovered an actual piece of memory, or is she glad to have touched a nerve, to have pleased him with her power of narrative? Or both? At one point in the novel, we see one of Grace's few solitary struggles with the memory of her possible (probable?) romantic involvement with Mr. Kinnear. She displays an unsure or even revisionist memory in her narration as a series of questions and lucid dreaming. All of her stories are qualified, but understandably so: "Did I push him away? Did he say I will soon make you think better of me? .... It might have happened" (296). Her recounting of the dreams is also undermined by the repetition of the phrase, "I think I sleep" (297-298). Worse yet is her explanation of the recurrent dreams as the reason she was put 
into the Asylum. She explains, "[t]hey said they were not dreams at all, Sir. They said I was awake. But I do not wish to say any more about it" (314).

The indeterminacy of Grace's labyrinthine narrative is linked to Grace's possible submission to, and resistance of, Simon's authority in the context of his professional endeavors to get at her lost memory. Accordingly, the momentum of the narrative is illustrative of her sanity or insanity, guilt or innocence. When Simon is gone, the story continues. When he is deemed unfit to hear, the story continues. She says on one occasion, "today I must go on with the story. Or the story must go with me, carrying me inside it, along the track it must travel, straight to the end, weeping like a train and deaf and single-eyed and locked tight shut" (298).

The need of a story to move toward its empty spaces is repeated again and again in the suspenseful avoidance of the cellar in almost every mention of the Kinnear house: "We đid not go đown into the cellar at that time" (212), "I attempted to run out, and he yelled and swore, and said I must open the trapdoor in the hall. I said, I won't; he said, You shall" (319); and "With a fine showmanship, the housekeeper saves the cellar till the last," saying "she was hid over by that wall. Though why they bothered to hide her, I don't know. Crime will out, and out it did" (385-386). The cellar, like Grace's lost memories, may carry too heavy a burden of concentrated evidence, and it might be our struggle to project a neat narrative that makes it so. Grace says, "When you are in the middle of a story it isn't a story at all, but only a confusion ... It's only afterward that it becomes anything like a story at all. When you are telling it, to yourself or to someone else" (298). Thus, we can see how we might ourselves have yielded to the demand for plausibility: what do we believe about narrative if we refuse to accept the possibility of a false or misguided heroine/storyteller?

Simon Jordan's narrative is amenable to Bakhtins' theoretical understanding that discourse often "displays how yesterday's and today's politics appear in dialogue" (292). Atwood's construction of Simon's narrative reveals his process of redefining himself in a world where the structures of yesterday's patriarchy have not yet disappeared. In the course of the novel, Jordan leaves the area, seeing himself on the verge of making a name for himself in the study of amnesia. He remains committed to his persistent beliefs about gender and cultural difference. Alexandra Dundas Todd describes the general pattern of doctors and women patients falling into "prescribed roles," and how "the doctor's role as questioner and the patient's role as answerer reveal the linguistic dominance of the doctor" (17). Simon's trauma results, in fact, because his beliefs are inadequate to explain his present experience. Atwood shows Simon as having projected onto Grace the Victorian stereotypes and beliefs about women. In his first encounter with Grace in prison, Grace entangles Simon in her romantically reconstructed narrative. He says:

The morning light fell slantingly in through the small window high upon the wall, illuminating the comer where she stood. It was an image almost medieval in its plain lines, its angular clarity: a nun in a cloister, a maiden in a towered dungeon, awaiting the next day's burning at the stake, or else the last-minute champion come to rescue her. The cornered woman; the penitential dress falling straight down, concealing feet that were surely bare; the straw mattress on the floor; the timorous hunch of the shoulders; the arms hugged close to the thin body, the long wisps of auburn hair escaping from what appeared at first glance to be a chaplet of white flowers - and especially the eyes, enormous in the pale face and dilated with fear, or with mute pleading. (68)

Atwood uses images that recall the Victorian iconography of the passive, silent woman in order to emphasize the subjection of women to certain masculine stereotypes which emphasized women's appearance as obedient, frail, and open to subjection and domination.

The images that come to Simon's mind resemble the paintings of the Pre-Raphaelites, where women are portrayed as innocent creatures who need to be rescued by a male champion - in this case, in the form of a doctor. Simon has projected the cultural ideals of what an outcast woman should look like onto Grace before even meeting her. As critic Maria Medlyn reminds us, "This was a period" "of both extreme sexual oppression and the assumption that males were entitled to female bodies" (5). And, indeed, on account of Grace's narrative and her beauty, Simon starts regarding her as a sexual creature: "[t]here is a passion in Grace somewhere, he's certain of it, although it would take some hunting for it. And she'd be grateful to him, albeit reluctantly" (452). Obviously, this desire for female-as-mistress is culturally rooted, as is the assumption that he is entitled to her favors even if they are "reluctantly" given. (The casual assumption that exploitation - or even rape - is acceptable cannot sit well with the reader of the present day.) As constructed, Simon is a classic sufferer from the Freudian notion of the Madonna-whore complex. Referring to this impossible schism, calling it "the myth of 'two women," George Watt elucidates that there was "the pure one to be married, the other to be used". So "keeping the two worlds apart was essential for the preservation of the status quo" (8). On his return from Toronto and Kinnear's house, Simon fantasizes about living in that house, "with Grace as his housekeeper. Not only his housekeeper: his locked and secret mistress...And she'd be grateful to him, albeit reluctantly. Gratitude by itself does not enthrall him, but he likes the idea of reluctance" (388). If Simon likes the idea of reluctance, he has no doubt been intrigued by Grace's outward prudishness and by her avoidance of telling him what he wants most to hear. He also has an unhealthy desire to have power over the already powerless. 
Simon's (dialogic) narrative is best understood as an existential attempt to reaffirm his concept of masculinity and manhood in a world which threatens its very conceptualization. In his essay "The Other Question," Homi Bhabha offers a possible elucidation of Simon's narrative discourse. Bhabha accounts for the durability of seemingly fixed cultural identities as "the excess" of the signification of "the other." He notes how the oppositions used to distinguish "others" from the dominant culture serve a stabilizing function: they seem to reify, confirm, and maintain the alien sense of "the other" (18-37). Bhabha also suggests that "otherness" is an allusion to difference. In the case of Alias Grace, a marginal woman has not yet been expressed within the dominant discourse. Furthermore, Gayatri Spivak argues, gender seems the issues of cultural differences among women become absorbed in the address of sexual imbalance (262). This notion of "others" arguably points to the problems of reading Alias Grace as the narrative discourse of the murderous woman [the offended Alias Marks]. It would argue that woman, as a category independent of class and heritage, occupies the space of the other.

As Simon's discourse narrative dialogic proceeds from a world in which he shares his self-assurance and privilege with one half of the human race, it marks only his distance from his traditions as well as his existential authority. Certainly, within oppositional frameworks, Simon crosses gender boundaries by displaying his inability to sustain self-control. Grace presents inner defiance to all that would subjugate her existential individualism. She outwardly represses her true nature and forces it to become a state of interior turmoil and monologue. Simon, under this embarrassment and awkwardness,-gradually loses the ability to keep a perspective on what the 'truth' is and where the boundaries of 'reality' merge with 'illusion'. He becomes lost in Grace's world of disguise, manipulation, and intrigue, which conceals the 'truth' and distorts 'reality'. His sense that Grace is leading him astray becomes clear when he remarks, "I can't shake the suspicion that, in some way I cannot put a finger on, she is lying to me" (438). His narration is marked by the scraps and patches of his inner conflict with a "given" truth. It unfolds in a disorganized collection of voices and fragments of remembered materials. His dreamy photography of Grace is changed when he perceives that "[h]er eyes were unusually large, it was true, but they were far from insane. Instead, they were frankly assessing him. It was as if she were contemplating the subject of some unexplained experiment; as if it were he, and not she, who was under scrutiny" (68).

Grace is thus seen by Simon as the epitome of the ambiguous, demonic femme fatale "of a curious frigidity, cold but sensual, erotic but invulnerable" (qtd in Lee 68), whose aim is to destroy men. He thinks to himself, "I have cast my nets into deep waters, though unlike him, I may have drawn up a mermaid, neither fish nor flesh but both at once, and whose song is sweet but dangerous" (490). The anxiety he feels is expressed in both the profane use of a quotation from the Christian Bible (the allusion to "deep waters" is a reference to Luke 5:1-11) and the reference to classical Greek mythology (sirens were mermaid-like creatures who lived in the sea and sang sweetly in order to lure sailors to their deaths). Notably, there is no mention of his personal choice in the matter.

He is caught in a trap. The woman who should have been remorseful and/or clinically insane claims the place of the psychiatrist with a freedom that Victorian women do not typically appropriate. Simon senses that Grace is controlling the situation and is enjoying their conversations as much as "one enjoys a game of any sort, when one is winning" (422). It is as though she is determining what she has to deal with and what approach it would be in her best interests to adopt.

This initial interaction sets the pattern for the rest of the narrative course between Simon and Grace. Simon continually feels as though he is "walking on quicksand" (103). Grace frequently disturbs the given stereotype of womanly behavior and contravenes the boundaries that Simon and patriarchy per se have established as the required norms. However, Grace violates boundaries covertly, as the lawyer who defended at her trial indicates:

Lying is not the correct interpretation and is, a severe term surely. Has she been lying to you, you ask? Let me put it this way- did Scheherazade lie? Not in her own eyes; indeed, the stories she told ought never to be subjected to the harsh categories of Truth and Falsehood. They belong in another realm altogether. Perhaps Grace Marks has merely been telling you what she needs to tell in order to accomplish the desired end. (438)

The abnormality of Simon's home situation in Mrs. Humphrey's house destroys his studied self-image even more. Beginning with the unpleasant servant, Dora, Simon is sucked into the details of a dishonored household in which he never planned to be more than an anonymous resident. He has the charm that attracts "women of the better classes, married ladies especially, with blameless reputations...to him as if he possessed some priceless but infernal treasure" (81). For her, the treasure is to refashion the respectable fantasy of her loveless marriage. In his illicit relationship with Mrs. Humphreys, he again faces himself as a fraud. He pays the individual cost of a socially constructed infantilization of women. In being the savior of an infantilized woman, he must accept her appreciation. Her "pretence of aversion" implies "that she's offering him her body as a kind of payment" (365), and this deceptively leads Simon to misperception and confusion.

Grace is hypnotized by the "Neuro-Hypnotist" Dr. Jerome DuPont at a telling interlude in Simon's narrative. Readers once again fail to have confidence that hypnosis can be used to reveal the truth. Because we know that Grace and Dr. DuPont are old 
friends, his influence on the hypnosis is inevitable, whether we believe the hypnosis to be real or not. (The reader might also consider the "Neuro-Hypnotist" to be a charlatan - why else might he be eking out a living as a peddler elsewhere in the narrative?) How precisely he prepares Grace on the day of the hypnosis is uncertain: he could just as easily have suggested a script to her as he could have tried to relax her in a sincere attempt to get at the bottom of her amnesia. Moreover, the hypnosis does not define - or even explain - the relationship between Grace and Mary Whitney's voice. It does not confirm that Mary Whitney is a spirit in possession of Grace's body (a metaphysical explanation for the voice that is not Grace's own). Nor does it posit that she exists as a distinct personality within Grace herself (a psychiatric explanation of the phenomenon). Since the results of the hypnosis are not amenable to a knowable discourse - they do not yield definitive knowledge of any kind - even more, doubt is cast doubt on its effectiveness. Therefore, hypnosis - the method that was itself intended to supply answers - actually sustains a range of alternative hypotheses - that Grace was manipulated into committing murder, colluded with the murder, or murdered the victims in a fit of insanity. Equally, it could be that Mary Whitney's spirit was avenging herself on the male gender for her botched-abortion-induced death or that Grace's denied internalization of anger at the prejudice of the privileged protection of her wealthy male employer (what Freud would call, in the next century, the return of the repressed). When, in the dream, Grace (or Mary) says of the murders, "The wages of sin is death. And this time the gentleman died as well, for once. Share and share alike!" (401).

However, hypnosis constructs an exaggeration of the truth to be believed. Grace's voice in the middle of Simon's narrative is an additional conduit through which Atwood projects Simon's increasing self-doubts. The ostensibly agency-less (voiceless) voice actually reveals how he struggles to make Grace's voice adapts to his own desires. Indeed, the psychological premises of the text appear quite different if we consider that this voice reveals Simon's imagination of how Grace speaks, instead of her own recounting of truth. If this section of the novel is read as Simon's imagination of how Grace tries to control her own existential destiny, then this context places him as the young male in the fantasy of his own life. Yet Simon sees for himself what Grace faces in terms of truthfully telling her story. He tells her "you can barely perceive right or wrong when you are in the middle of what only later becomes a story; that there are forces stronger than your own mind that cause you to act and to want to forget you acted; that our own perception constructs who we are as much as who we are constructs our perception" (437).

Simon's voice is effectively lost in the last section of the narrative discourse. Unpredictably, Simon is unable to hold himself up, and he abandons any authority and self-possession he ever had in order to elicit Grace's revelation. Unable to keep up the front of the Victorian gentleman for long, he is emotionally aware of himself as a fraud. Actually, when Grace ends her narrative, he is not even there to hear it, having fled suddenly from Kingston and his mistake with Rachel Humphrey under the guise of researching Grace's story in Toronto. However, Simon's own sense of himself as a self-determined psychiatric authority is shaky from the beginning. His fragmented self is further emasculated with the recognition that he cannot write the report necessary to support Grace's petition for freedom. He envisages himself "married to Faith Cartwright and imprisoned in an armchair by the fire, frozen in a kind of paralyzed stupor, with his dear wife winding him up gradually in colored silk threads like a cocoon, or like a fly snarled in the web of a spider" (293). Further, we see him unable to write to his friend Edward or to his mother, crumpling attempt after attempt in his effort to reconstruct the façade of self-assured success he knows he must maintain:

He crumples the page and drops it onto the floor. He will write a different letter. Ay dear Edward I trust you are in good health; I myself am still in Kingston where I continue to... But continue to what? What exactly is he doing here? He can't sustain his usual jaunty tone. What can he write to Edward, what trophy or prize can he show? His hands are empty, he has discovered nothing. (293)

These fragments become a vague narrative that reminds us of the white male patriarchal tradition from which Simon tries to narrate. They remind us of the strange surface of his story and this strangeness eventually amplifies Atwood's contrast between standard masculine perspectives and the world of Simon's involvements. Atwood performs his inability to understand the transforming outlines of his identifications. Without a community of discourse, he is forced to trade within the languages of the infantilized woman. These languages, however, are inhospitable to his desires and no other voice conforms to his needs. Ultimately, the style of his narrative reinforces his lack of internal assurance about who he is.

According to Bakhtins' theory, Simon speaks through two voices. If he becomes sympathetic, it is because he seems to lose control over any single voice that could define him. His masculine voice is compromised by feminine inflections, and so the principal devices that could ensure his superiority are destabilized. However, because he clings to the notion of personal, integrated authority, an imaginative unity of self, he is clearly annoyed, frustrated, by the world in which he lives. Basically, his societally-sanctioned autonomy, his position as the white male fraud, dominates in his narrative. But Atwood deconstructs the notion that gender positions sustain oppositional "givens" of power. To reclaim his old sense of order, Simon's only choice is to flee the world of inadequate boundaries, to flee to Europe and reestablish the dividing line between himself and the alien other. Consequently, Simon's combination of voices is an especially powerful reinvestigation of the process of gaining authority through speech. Because he overtly occupies the space of white male privilege in the text, Atwood uses his historical position to create a voice-over effect in her novel. While he is ostensibly at his most autonomous, his instability under the protection of his privilege 
writes large the inadequacy of such codifying structures. The language and definitional systems of patriarchy thereby operate as acts of aggression upon his experience. He becomes both angry and anxious as he cleaves to the traditions that control his perceptions.

In conclusion, Margaret Atwood's Alias Grace recuperates the voice of the supposedly-murderous woman by revising the myth of woman's silence and subjugation. Atwood reveals the experientially undetectable in Bakhtin's theories of voicing. She emphasizes how characters suffer in their attempts to make their experience conform to pre-established definitions for their existential existence. The possibility of harmony haunts the narrative discourse of Alias Grace precisely because the history of such identifications marks the present struggles of Atwood's narrators. The manipulated or insane personality suddenly seems at the moment of expression. It exists in spite of - indeed, within - specialized vocabularies that insist upon the absolute differentiation of self and other. To be more precise, 'otherness' is articulated within normative discourses as an incomprehensible absurdity. The novel challenges the allegory of the manipulated persona as insane. The novel unfolds within the complex mythologies of Victorian femininity, within the socioeconomic setting of femininity, as experienced by pretty young women of the servant class like Grace. Cultural and sexual differences are thus managed. By emphasizing the destructiveness of construing this complex persona as insane, Atwood writes in advance of feminist theory concerned with the negative effects of identifying people as distinct and selfcontained representations of "otherness". She deconstructs strict codes of sexism as she actively engages her narrative voices in the performance of their existential identities. Because her speaking voices are required to practice "double-voicing" in order to be heard, through presenting the reader with both voices, Atwood recuperates the moments of existential liberation to be heard from emergent voices.

\section{References}

[1] Atwood, Margaret. Alias Grace. New York: Anchor Books /Doubleday, 1997.

[2] Bhabha, Homi. "The Other Question." Screen 26, no. 6 (1983): 18-37.

[3] Bakhtin, M. M. The Dialogie Imagination. Edited by Michael Holquist. Translated by Caryl Emerson and Michael Holquist, Austin: Univ. of Texas Press, 1981.

[4] Brooks, Peter. Reading for the Plot: Design and Intention in Narrative. New York: Knopf, 1984.

[5] Creighton, Joanne. V. "The Reader and Modern and Postmodern Fiction." College Literature 9, no.3 ( Fall 1982):216-30.

[6] Dow, Isabella. "Alias Grace' Tackles Psychological, Patriarchal Horrors." November 5, 2017 Updated June 1, 2020.

[7] Freidman, Ellen G. Breaking the Sequence: Woman's Experimental Fiction. Princeton: Princeton Univ. Press, 1989.

[8] Freud, Sigmund. Introductory Lectures on Psycho-analysis (1916-1917). Trans. James Strachey. New York: Norton, 1966.

[9] Hampl, W. S. "Margaret Atwood Revisited." Studies in Short Fiction, 36(4), 443-445. (1999).

[10] Hutcheon, Linda. The Polities of Postmodernism. London: Routledge1988.

[11] Lee, Elizabeth. "The Femme Fatale as Object." The Victorian Web. Ed. George Landow. Brown University. 1997. 4 February 2001.

[12] Medlyn, Maria. "Female Insanity: The Portrayal of a Murderess in Alias Grace," Scholarly Horizons: University of Minnesota, Morris Undergraduate Journal: Vol. 4: Iss. 2, Article 6. (2017):1-17

[13] Ramchand, Kenneth. The West Indian Novel and Its Background. 2nd ed. London: Heinemann, 1983.

[14] Sartre, Jean-Paul. Being and Nothingness (1943). Trans. Hazel E. Barnes (1953). New York: Washington Square Press, 1966.

[15] --- . "Existentialism Is a Humanism." Existentialism: from Dostoevsky to Sartre. Ed. and Trans. Walter A. Kaufmann. New York: New American Library Press, 1957: 287- 311.

[16] Spivak, Gayatri Chakravorty. In Other Worlds. New York: Methuen, 1987.

[17] Todd, Alexandra Dundas. Intimate Adversaries: Cultural Conflict Between Doctors and Women Patients. Philadelphia: U of Pennsylvania Press, 1989. Pp. 167. Language in Society, 19(4), 596-599.

[18] Stein, Karen. Margaret Atwood Revisited. New York: Twayne Publishers, 1999.

[19] Wellinghoff, L. A. Alias Atwood, Alias Author, Alias Murder. Clues: A Journal of Detection (McFarland \& Company), 29 (2). 2011.

[20] Watt, George. The Fallen Woman in the Nineteenth Century English Novel. Totowa, NJ: Barnes \& Noble, 1984.

[21] White, Hayden. The Content of Form: Narrative Discourse and Historical Representation. Baltimore: John Hopkins University Press, 1987. 